\title{
FACTIONALISM AND COLLECTIVE LABOR IN COPPER AGE IBERIA
}

\author{
FACCIONALISMO Y TRABAJO COLECTIVO DURANTE LA EDAD DEL COBRE \\ PENINSULAR
}

\section{PEDRO DÍAZ-DEL-RÍO $(*)$}

En recuerdo de Charo Lucas

\begin{abstract}
This contribution presents a political model for interpreting the large Copper Age settlements of the Iberian Peninsula. It considers that factional competition within segmentary societies creates conditions that both promote aggregational processes and undermine them (frequently leading to group fission). The critical moment when factional leaders may consolidate their power is the initial mobilization of a collective workforce. If such consolidation fails to take place, factional competition and the development of household interests multiplies the fronts on which resistance to leaders can take place. This model is applied to the archaeological record of the Upper Guadalquivir. The results of this analysis suggest that the dynamics of large-scale aggregation only can develop in places were there exists a sufficiently large population, abundant potential resources, and the technology by which resources and population can be exploited and maintained. A model that will explain the variability observed in the Iberian Copper Age must also consider political factors, however.
\end{abstract}

\section{RESUMEN}

Este trabajo presenta un modelo político para la interpretación de los grandes poblados de la Edad del Cobre en la Península Ibérica. Considera que la competencia entre facciones en sociedades segmentarias genera las condiciones para el auge de procesos de agregación, y es a su vez. la base de su debilidad, situación que frecuentemente provoca la fisión de los grupos. El momento clave para la con-

(*) Departamento de Prehistoria, Instituto de Historia, CSIC. C/ Serrano 13, 28001-Madrid, España. E-mail: diazdelrio@ih. csic.es

Recibido: 25-III-04; aceptado: 30-V-04 solidación del poder de los líderes faccionales es el momento inicial de movilización de trabajo colectivo. Caso de no consolidarse, la competencia entre facciones y el desarrollo de los intereses familiares multiplica los frentes de resistencia. El modelo se aplica al registro arqueológico regional y local del Alto Guadalquivir. Finalmente se sugiere que la dinámica de agregación a gran escala únicamente puede darse en aquellos lugares en los que exista suficiente población, recursos potenciales y la tecnología suficiente para su explotación y mantenimiento. Sin embargo, para explicar la variabilidad observada durante el Calcolítico de la Península Ibérica se requiere incorporar factores políticos.

Key words: Kinship. Factionalism. Collective labor. Aggregational processes. Fission. Iberia. Copper Age.

Palabras clave: Parentesco. Faccionalismo. Trabajo colectivo. Procesos de agregación. Fisión. Península Ibérica. Edad del Cobre.

\section{INTRODUCTION}

In kinship modes of production (Wolf 1981), and under conditions of low agricultural intensification, aggregational processes are key for a comprehensive understanding of the rise of social hierarchies (Beck 2003). This is so because concentration of the labor force is the most straightforward means by which surplus can be increased. But segmentary societies are inherently factional, and fission is the main way their components maintain political independence (Sahlins 1961; 1972). Unpleasant leaders are either abandoned or eliminated (Clastres 1980). Even so, and as world prehistory shows, impressive aggregations often did occur, 
and social hierarchies occasionally did arise without intensive agriculture. For archaeologists this problem raises at least two key questions: first, how could densely occupied settlements come into being, and secondly, what processes prevented them from fissioning.

In this paper I consider factionalism and labor mobilization to be at the core of both questions. Competition between factions creates conditions that may attract followers (Brumfiel 1994): the promise of immediate and future material benefits, and the dangers of vulnerability, either physical or psychological. Communal labor mobilizations, often involving inclusive ritual action accompanied by feasting (Beck 2003; Brown 1997; Dietler and Hayden 2001), create economic and symbolic capital and practices of interdependence that restrain segmentation (Bujra 1973: 143).

Without further economic intensification and a trend towards elite monopolization of "the means of reproduction of the universe and of life" (Godelier 1978: 767), both actions would have a limited temporal effect. The major problem for chiefs in most segmentary aggregational processes is not access to surplus, which may flow upwards through kinship and lineage status lines (1), but maintenance of the stable labor pool that can produce it. Centrifugal dynamics frequently develop under several conditions. In most instances, if not all, chiefs tend to materialize and display their wealth and power (DeMarrais et al. 1996) through increasingly exclusive ritual practices, consumption patterns, exchange mechanisms, and specialized ritual or military paraphernalia (Brown 1997; Earle 1997; Gilman 2001; Knight 1986; Kristiansen 1984). Elites make themselves known to one another through conspicuous consumption (Gilman 1991: 151). The involvement of followers in collective labor mobilizations and ritual events is difficult to sustain, and consequently interdependence is loosened. Unless supported by some form of coercion, the absence of benefits does not encourage solidarity. Economic stress may also affect the decision of followers. Unpredictable harvests may not be an immediate problem for the powerful, but may force the poorer to depend on charity, shift to other resources, or abandon the settlement. In other cases, household interests confront communal integration (Marx in

(1) This becomes a formal tribute only when effective control over the means of production can be exercised by rulers, and surplus is extracted through non-economic coercion (e.g. physical, psychological or cultural sanctions).
Shanin 1983). This is so because social contiguity engenders competition (Bujra 1973: 136), multiplying the opportunities for shifts in factional support. All these centrifugal dynamics are generated when vertical and horizontal tensions become daily features of social interaction, so that fission becomes an attractive option.

In kin-organized systems, the development of forms of internal and external factionalism are not the consequences of chiefly power, but their precondition. Unfortunately for chiefs, they are also their potential ruin. Even if commoners are caged (Mann 1986), most rulers spend a considerable amount of wealth and energy in attempts to suppress potential and effective rivals, by attracting their followers, provoking their economic ruin or, not uncommonly, by murdering them. This factional contradiction, that is, factions as preconditions and potential ruin of chiefly authority in kinbased societies, is a key aspect of social interaction (Sahlins 1961; Brumfiel and Fox 1994).

For archaeologists, one of the best ways to analyze the various forms by which chiefs gain and lose their power through this political contradiction is to focus on clear cases in which regional polities develop in isolation. In areas where chiefdoms were a generalized phenomenon, the options of resisting a particular chief's power would have been limited to accepting that of another similar potentate. The most evident and available case studies are societies in which economic intensification is limited, but where considerable concentration of population and massive investments of labor in collective works stand out as their most salient feature. That is, places where monumental architecture is the main and earliest form of conspicuous consumption. In the following section we will analyze the evolution of one such case, the late third millennium BC Spanish site of Marroquíes Bajos.

\section{MARROQUÍES BAJOS (JAÉN, SPAIN)}

The case of the 113 ha Late Copper Age site of Marroquíes Bajos, in the Spanish Upper Guadalquivir Valley, illustrates the instability of leadership in emerging chiefly societies. It is a remarkable example of two key features: the role of intergroup strife in the process of aggregation of early agricultural societies, and the development of horizontal factionalism through the institutionalization of an extended household community. 

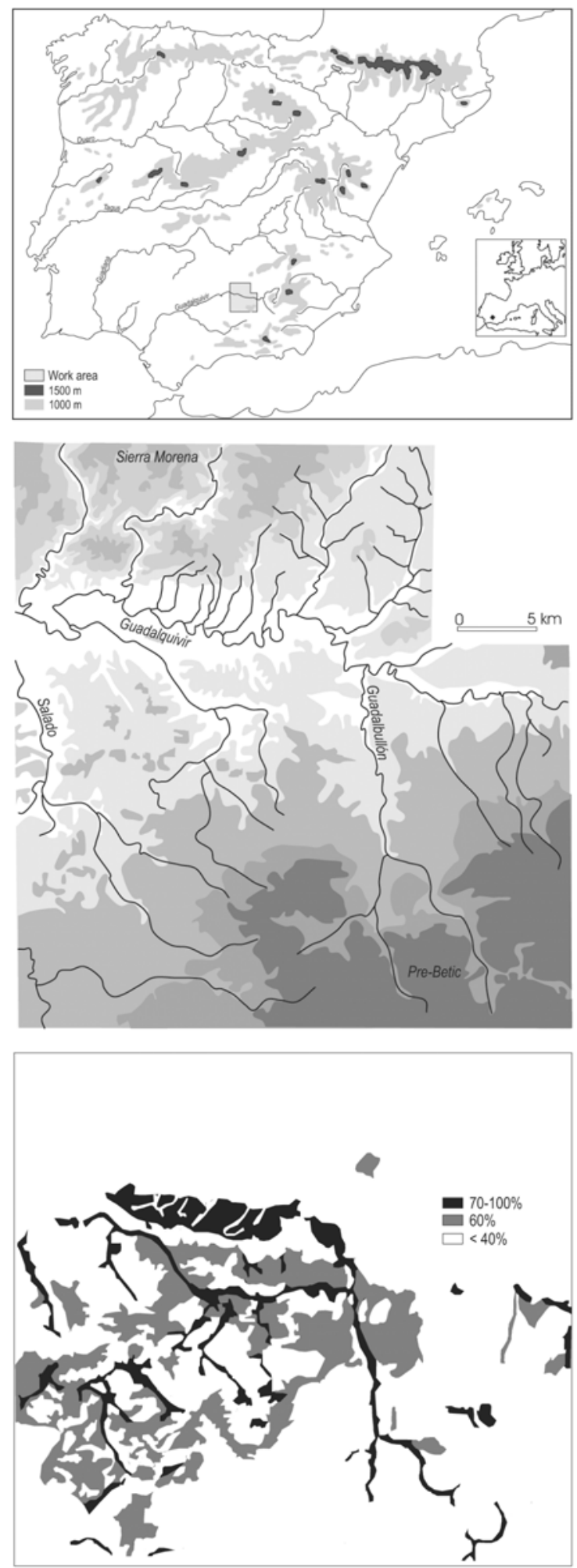

Fig. 1. General and detailed localization of study area in the Iberian Peninsula. Land productivity of study area (modified from Nocete 1994a).
The Upper Guadalquivir Valley (Fig. 1) is an east-west oriented river basin limited by the mountains of Cazorla-Segura to the east, Sierra Morena to the north and the Pre-Betic to the south. The valley opens to the west, connecting the area with lower Andalucía. This depression is asymmetrical. To the north, mountain chains are only a few kilometers away from the river. To the south, an extended low and gentle hill relief, known as the campiña, connects basin and mountains. Good agricultural lands are patchy (Fig. 1). The contact between limestones and clays create the conditions for frequent permanent springs, a strategic resource during prehistoric and historical times. Both north and south mountain chains are crosscut by smaller valleys that facilitate inter-regional connections (Ruíz et al. 1986: 273; Harrison and Orozco 2001). These mountains have abundant quarries for the production of chert sickles, polished hoes, axes, and grinding stones. They also yield malachite (Nocete 2001: 44) for a domestic and technologically simple copper metallurgy.

This region was thoroughly studied during the 1980s through extensive survey and selective excavation programs (Nocete 1989; 1994a; 1994b; 2001; Ruiz et al. 1986). A six-phase later prehistoric sequence was established from an analysis of 1052 undecorated rimsherds recovered from stratigraphic contexts at four sites. The ceramic distinctions were then applied to the surface collections obtained in the survey (Nocete 1989: 98-141). The work did not, however, take into account various factors that can affect the reliability of such stylistic sequencing. We are not told, for example, the nature of the stratigraphic contexts the assemblages from which were used to build the sequence, the size of the samples obtained in the surface collection and the degree to which they are representative, or just what the diagnostic differences between the undecorated ceramics of the various phases in fact are.

The chronological assignment of these phases is also problematic. Only 14 absolute dates are known for the region (Fig. 2), but Nocete's (1994a) phasing was originally based on five, one from the site of Cortijo de la Torre and four from Albalate. Consequently, the sequence developed by Nocete (2001) also lacks the support of absolute dating. Nevertheless, this study remains the only reference for interpreting the evolution of regional settlement pattern.

The impressive site of Marroquíes Bajos was discovered in the mid 1990s, when the regional capital 


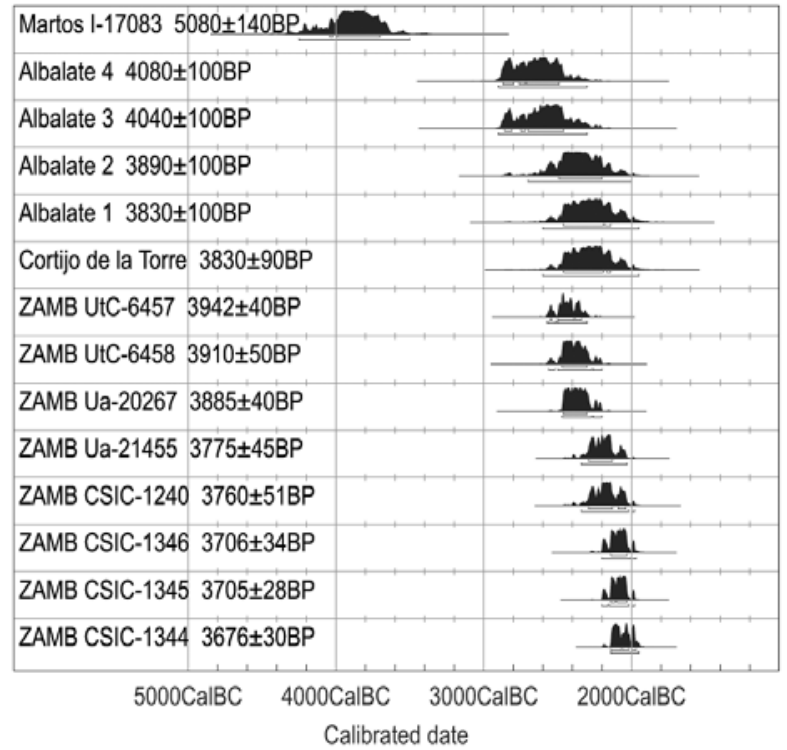

Fig. 2. Calibrated radiocarbon dates from the Upper Guadalquivir valley (Oxcal v3.9). Polideportivo de Martos (Lizcano et al. 1997), Albalate and Cortijo de la Torre (Nocete 2001, no laboratory references provided) and ZAMB-Marroquíes Bajos (Zafra et al. 1999 and 2003).

city of Jaén expanded northward. The excavations consisted, therefore, of rescue archaeology in an urban context: different exposures dug by different archaeological teams combine to reveal a 113 hectare Copper Age site. This data set has allowed a preliminary interpretation, essentially based on the site's architectural evolution (Hornos et al. 1998; Zafra et al. 1999 \& 2003). The available information is of course partial, mainly a result of the inherent problems of this kind of archaeology when dealing with a site of this size. Lizcano et al. (2004) have summarized some of the main difficulties: the lack of detailed information about the site's stratigraphy, the absence of analyzed cultural assemblages, and the limited knowledge on the stratigraphic and stylistic correlations between the different exposures. These critics base their comments on the results obtained in the excavations of some exposures (Pérez Bareas and Cámara 1999; Pérez Bareas and Sánchez 1999; Burgos et al. 2001 a, b \& c), results that they themselves do not present in full, however.

In spite of the evident deficiencies of the information from the survey of the Guadalquivir campiña and the excavation of Marroquíes Bajos, that both sequences were developed independently gives some support to the following analysis. In any event, the purpose of the present contribution is not so much to analyze the details of the clearly limited empirical evidence from these cases, as to underline the significance of the general pattern the two cases present for an evaluation of the political dynamics at a regional scale.

\subsection{The evolution of regional settlement patterns}

Six phases can be established with respect to the evolution of settlement patterns (Nocete 1994a and 2001) (Fig. 3). The earliest phase (phase 0) is defined by a relatively dense Neolithic colonization of the Guadalquivir river basin and some initial settlements in its southern tributaries. Eighteen small sites of less than 1 ha are known.

During phase I (fourth millennium cal BC) settlements expand throughout the main river valleys, particularly the Guadalbullón, with occasional occupations in the campiña. Some sites have a substantial increase in hectares (up to 12 ha), with smaller settlements in their surroundings, but there is no clear evidence of hierarchical arrangements (Nocete 1994a: 293). One of the best known sites is Polideportivo de Martos (Cámara 2001; Lizcano et al. 1997). Characterized by clusters of underground features surrounded by a small ditch enclosure, its most salient components are a shallow pit containing a multiple human inhumation, and several other pits with domestic animal burials. These domestic rituals have been related to an increasing importance of group identity, herding and territoriality (Cámara 2001: 56). Generally, there appear to be no differences in wealth or variability in consumption within or between sites.

Phase II (c. 3000 cal BC) sees a dispersed colonization of the campiña. Fewer and bigger sites suggest an aggregational process at a regional scale, which will peak during the following phase. The main observed pattern is the absolute abandonment of the Guadalbullón valley and a limited occupation of the campiña. The lack of occupations in this valley is probably contemporary to the first fortification of Los Alcores and Albalate, two stonewalled hilltop settlements located along the Salado River, $20 \mathrm{~km}$ west from the Guadalbullón. During phase II and III both settlements would see the sequential construction of impressive stone fortifications, four lines at Los Alcores and five lines at Albalate. They visually control the Salado River and an important amount of first class productive soils in the sur- 

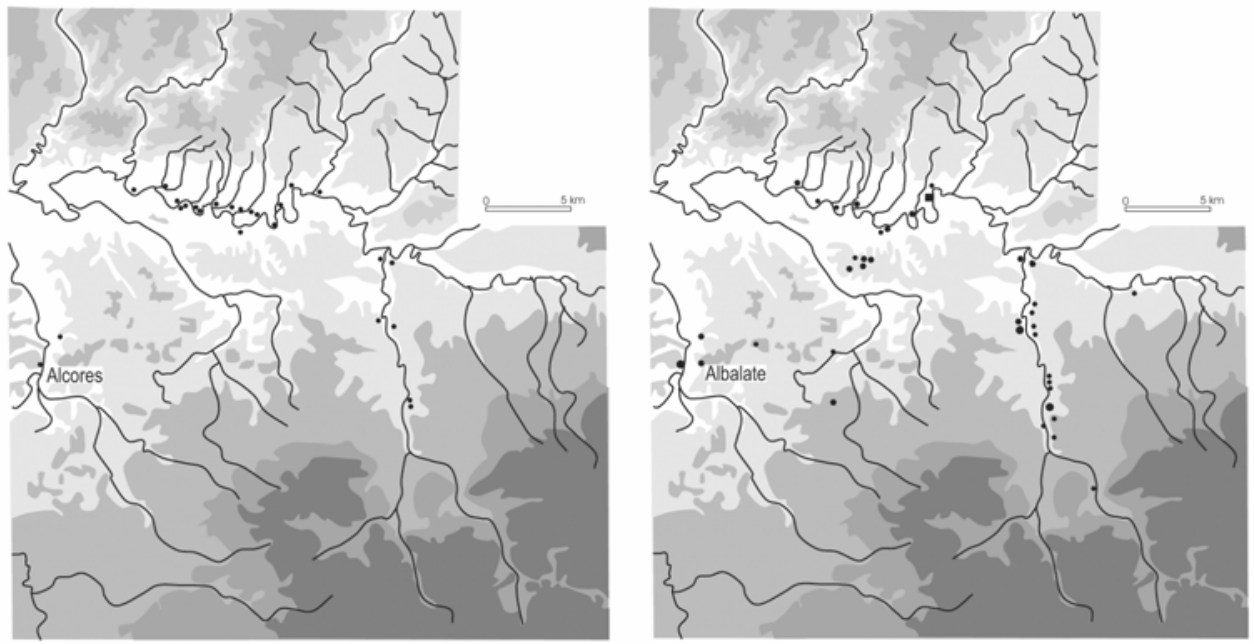

Phase 0

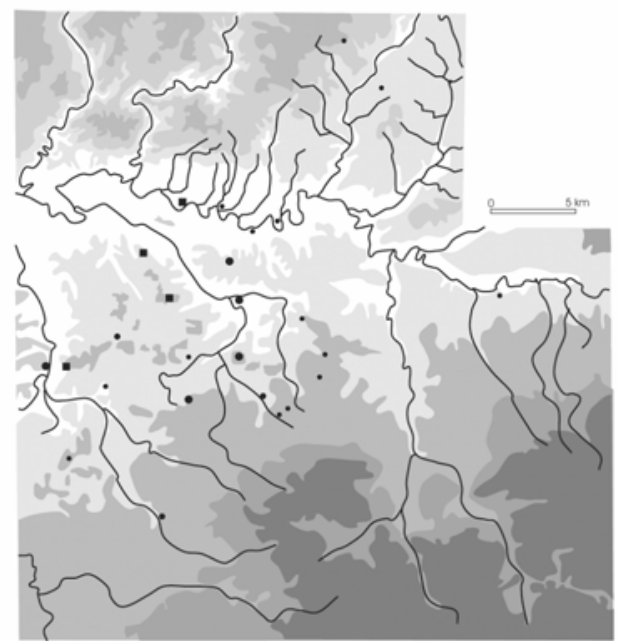

Phase l: c. 3750 cal BC

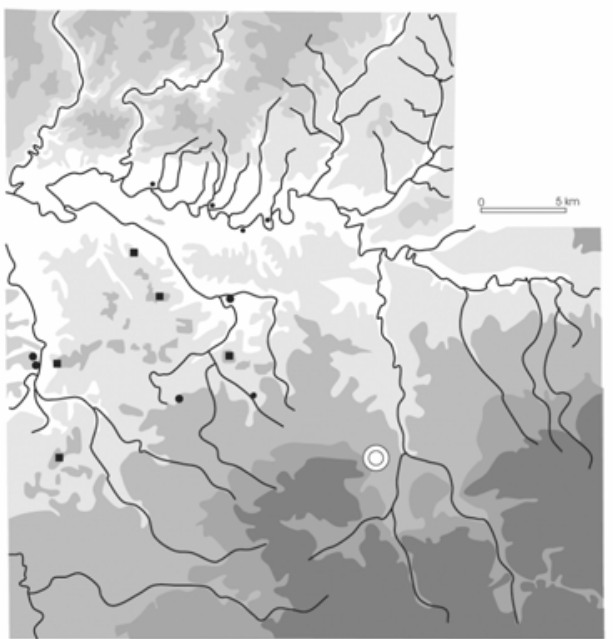

Phase II: c. 3000 cal BC
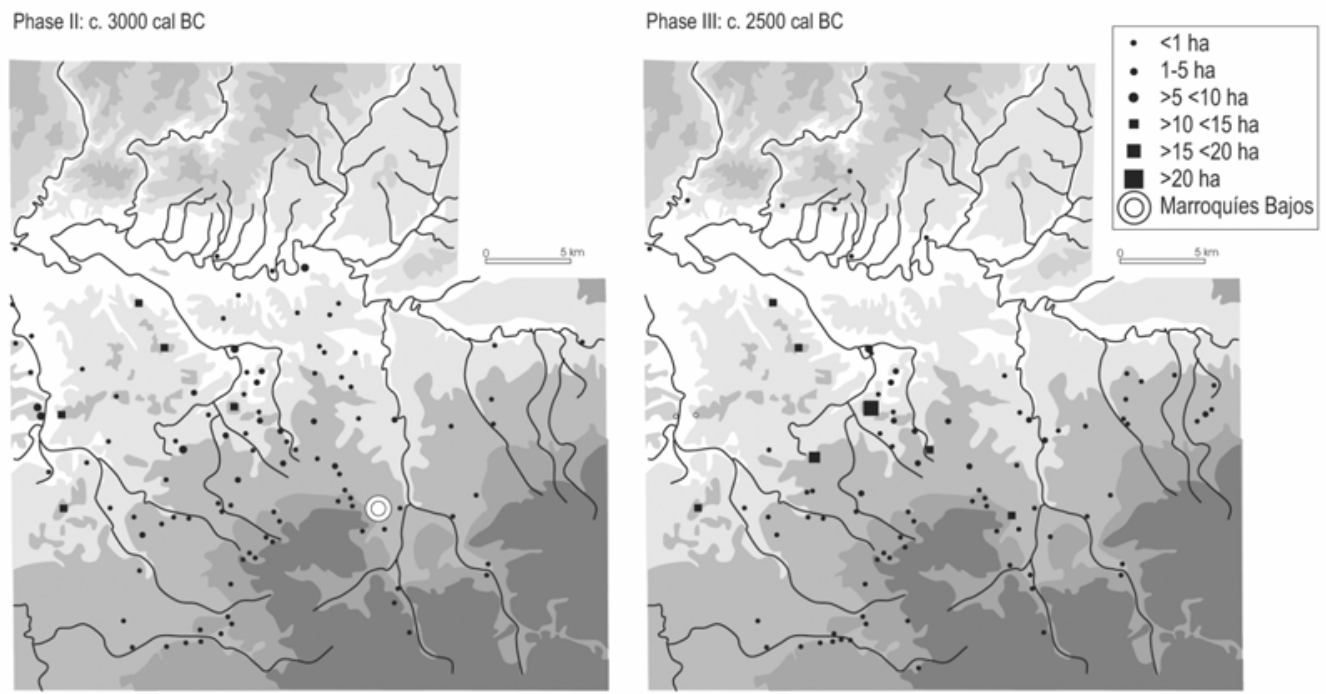

Phase IV: c. 2200 cal BC

Phase V: Beginning II millennium cal BC

Fig. 3. Evolution of settlement patterns (modified from Nocete 1994a; 2001). 


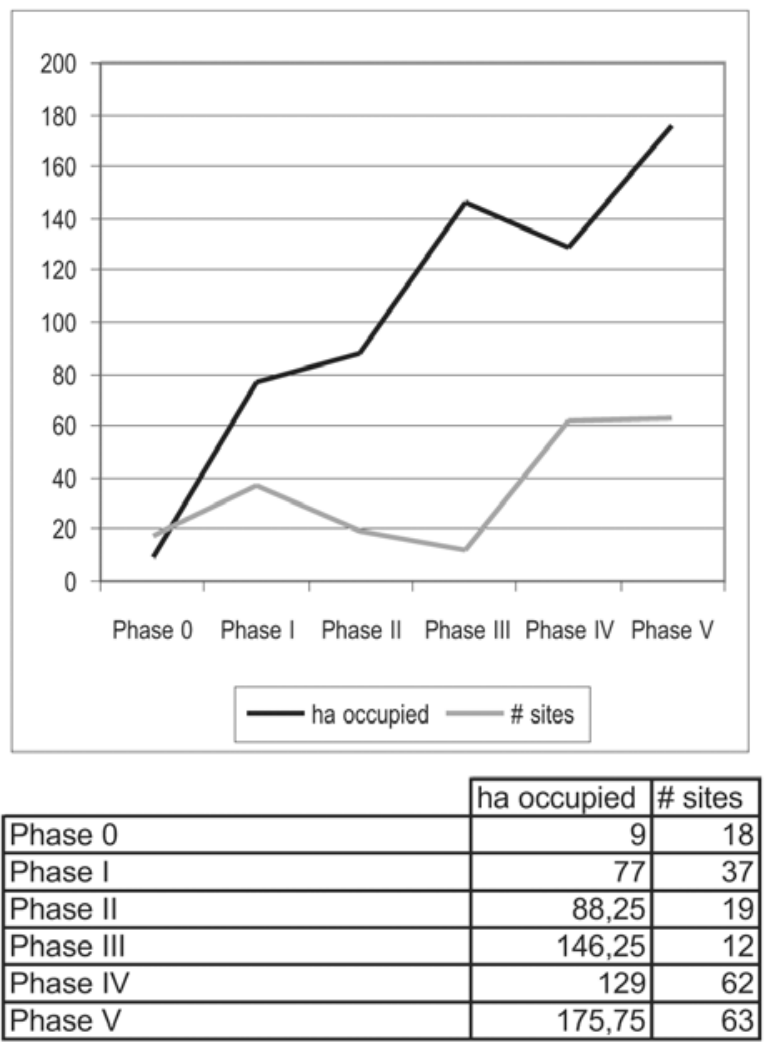

Fig. 4. Relation between size and number of settlements in the study area (data obtained from Nocete 1994a).

rounding areas. A near neighbour analysis shows that all contemporary sites are located at least 3 to $4 \mathrm{~km}$ apart, except for these two fortified sites, less than one kilometer away from each other (Nocete 1994: 294). This pattern has been interpreted as reflecting an increase in regional intergroup strife.

Phase III (c. 2500 cal BC) marks the decline in the number of sites (19 to 12) and an increase in their size (Fig. 4). The resulting pattern is one of an extremely dispersed occupation previously unknown for the region. Indeed, there are no settlements at all belonging to this phase in the $400 \mathrm{~km}^{2}$ southeast quadrant of the study area.

Phase IV (c. 2200 cal BC) sees a reversal of the previous pattern. The number of sites grows from 12 to 62 , with a clear expansion throughout the campiña. The coupled sites of Los Alcores and Albalate maintain and renew their fortifications, keeping a surrounding "buffer zone" with a low density of small sites. Nevertheless, some of the smallest settlements in the campiña were also fortified. This is the case of excavated site of Cazalilla, a 0.25 ha village surrounded by a stone enclo-

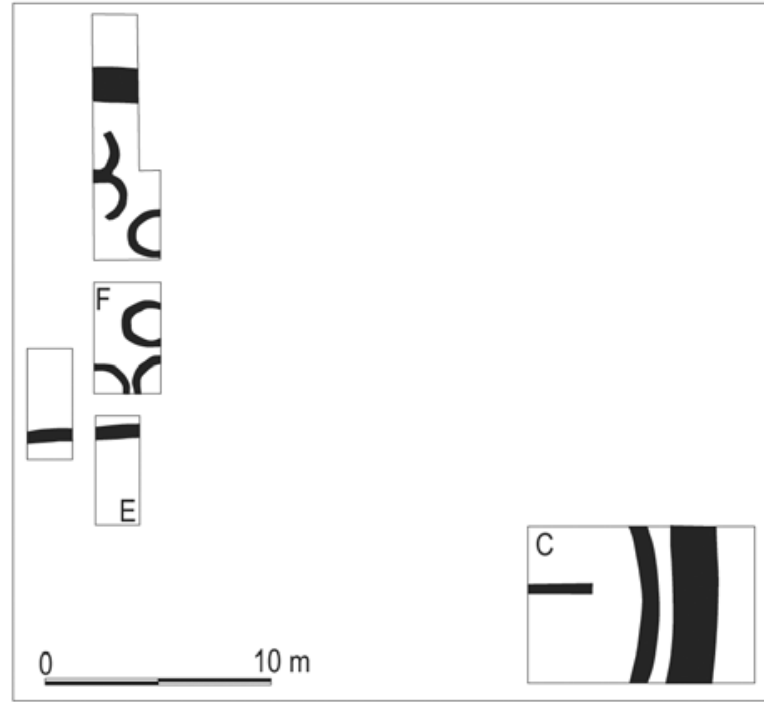

Fig. 5. Cazalilla, Phase II (modified from Nocete 1994a).

sure (Nocete 1994a) (Fig. 5). The interior shows a randomly organized distribution of very small huts $\left(3.14 \mathrm{~m}^{2}\right)$ and a contemporary big oval structure, which included evidence of a loom, and pottery for domestic consumption and storage. Contrary to what could be expected if this facility operated as some kind of centralized economic facility, no big storage jars or any other unusual items have been recovered. Both the size and internal distribution of the site suggest a communal use for this building. If the remains recovered in Cazalilla reflect a general regional pattern, settlements kept certain autonomy in production and occasional exchange, as indicated by the presence of obsidian, marine shell (Tapes Decusatus), and bell-beakers. Partially based on the evidence from Cazalilla, the analyst of the excavation argues for the existence of a strongly hierarchical (State) society for the region during the Copper Age (Nocete 1994), but he presents no evidence for differential consumption patterns. This suggests that inequalities inside the village of Cazalilla are far from evident. Long-distance exchange items are rare at this as at most other sites (2). As for bellbeakers, they are so commonly distributed by the mid third millennium that they are used by Nocete itself as a chronological marker for the phasing of settlements (3).

(2) In southern Iberia there seems to be an interesting correlation between size of sites and amount of long-distance exchanged items (see Harrison and Gilman 1977).

(3) As Harrison and Gilman note (1977: 101, footnote 12), it is not the presence-absence of bellbeaker but the variability in their concentration in certain sites that must be explained. 
By Phase V (beginning of the second millennium BC), sites that had the major role in the precedent phases are in complete decline. The whole region is now part of the Argar "culture", an emerging "Germanic" society (Gilman 1995) characterized by nucleated villages with rectangular terraced households, new forms of material culture, a shift to individual burials in domestic spheres, and an increase but generalized domestic production of metal weapons.

In summary, the spatial analysis of third millennium BC settlement patterns reflects a dynamic process of aggregation and fission, a cycling that we believe to be characteristic of unstable chiefly societies.

\subsection{The evolution of Marroquíes Bajos}

Marroquíes Bajos has been described as a Late Copper Age "macro-village" (Zafra et al. 1999) (4). It is settled on the lowlands adjacent to the hill of Santa Catalina, an area historically used for horticultural purposes because of its rich springs and high watertable. It is located in an important ecotone between the mountains and the upper Guadalbullón valley, potentially controlling access to rich wildlife, quarry resources of the sierra, and one of the main paths linking the Upper Guadalquivir valley and Southeast Spain. The evolution of its domestic architecture during the abovementioned phases can help us understand regional dynamics, because, as Brumfiel (1992: 555) notes, in agrarian societies "political change almost always involves the restructuring of household labor".

The process of aggregation begins some time around the first half of the third millennium BC. This may have been caused by an increase of regional strife. As Sahlins (1961: 326) suggests, "local autonomy breaks down [...] proportionate to the amount of $[\ldots]$ concerted action possible against other societies". During this phase, the site is defined by a generalized pattern of underground huts, silos, refuse deposits, and other domestic facilities, with no clear variation in size or wealth. The incor-

(4) In this section I will draw strongly on Zafra et al. 1999 and 2003, the only available information on Marroquíes Bajos intrasite dynamic. Their research is based on more than 100 unpublished rescue excavations (1995-1999). The main tendencies of the site are still supported by ongoing 2000-2003 excavations (Zafra personal communication may 2003).

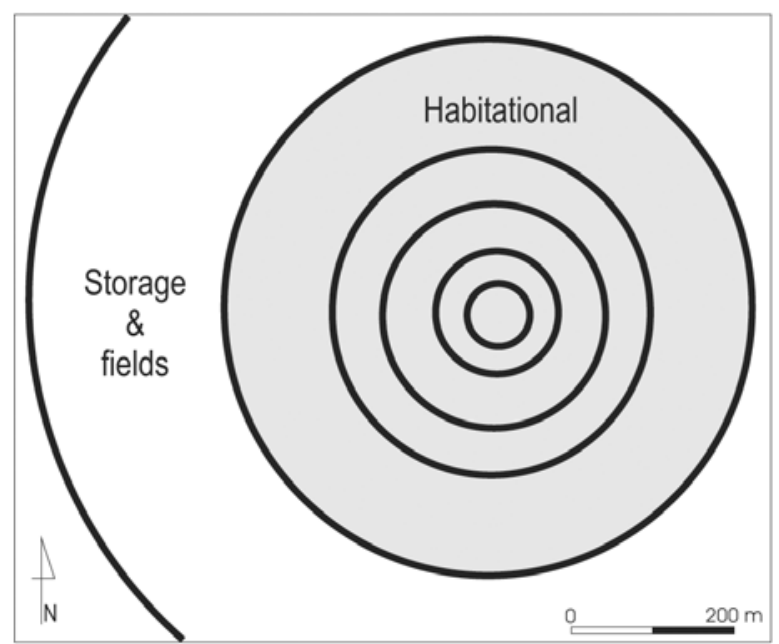

Fig. 6. Hypothetical plan of Marroquíes Bajos (modified following Zafra et al 1999: 83, fig. 3 \& Zafra et al 2003: 87, fig. 1).

poration of new social segments into an already settled population suggests that, during these earlier stages, some form of "politics of firstcomer primacy" (Kopytoff 1999) may have existed in order to guarantee access to land. Allocation of newcomers and distribution of land required specific ongoing mechanisms, specially needed "in the absence of unambiguous evidence of centralized, coercive social and economic management and unifying ideology" (McIntosh 1991: 203). I believe that this mechanism is precisely the rise of effective leading lineages, maybe through what Sahlins (1961) defined as a "massing effect". Consequently, emerging horizontal factionalism between lineages should be expected.

By 2450 cal BC (Phase III) Marroquíes Bajos probably becomes one of the few settlements in the Guadalbullón valley and eastern campiña (Fig. $6)$. Massive communal labor was invested in the creation of six ditches of variable width (6-10 m) and depth $(2-5 \mathrm{~m})$. The 34 ha fifth ring was reinforced by a $3 \mathrm{~m}$ high and $2 \mathrm{~km}$ long adobe wall with bastions, and the third by a 375 meters long wooden palisade and bastions. The settlement was further surrounded by yet another ditch, enclosing 113 ha (almost $4 \mathrm{~km}$ long), within agricultural fields, dispersed domestic and other smaller facilities were located. The six ditch enclosures have been described as a circular water capture and distribution system of more than 1 square $\mathrm{km}$ (Zafra et al. 1999: 82), but the atypical character of the proposed 'hydraulic enclosure' has raised some 


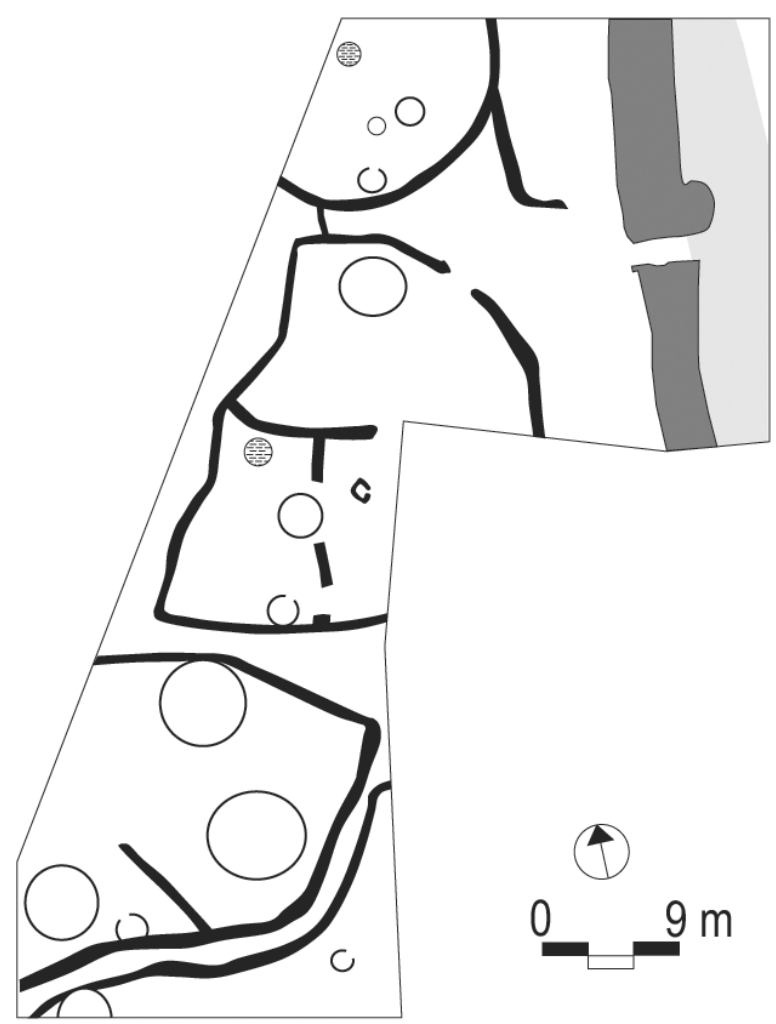

Fig. 7. Extended households compounds at Marroquíes Bajos (modified from Zafra et al. 1999).

doubts (5) (Cámara 2001: 194; Lizcano et al. 2004: 166-167). Be that as it may, archaeological evidence suggests that water did flow in and between enclosures, as natural sediments and radial ditches connecting the main enclosures seem to suggest (Zafra et al. 2003). But accepting that enclosures were originally designed as a unified irrigation system project has further implications with respect to the scale of economic intensification, something unknown until now for Copper Age Iberia. Without denying its potential use for irrigation, something that would require further evidence (Chapman 2003: 172), a reasonable option would consider its hydraulic function as a byproduct of the enclosing system.

During this phase, dwellings with circular foundation trenches are most common. Only one rectilinear structure has been partially documented inside the fifth enclosure. Spatial distribution of

(5) The fact that there is no prehistoric, historic or ethnographic parallel for circular irrigation systems, and that the same "circular pattern" is known in most Neolithic and Copper Age enclosures of western Europe gives certain support to critics. features at some exposures suggests that space may be organized by some structuration principles, with houses grouped around and oriented towards central open spaces, and increasing functional variability between buildings. Subterranean collective burials without any offerings have been documented in the surroundings of these open areas (Zafra et al. 1999: 87). Although available information is limited, it is suggestive to see this structuration as a pattern of multiple and related households, spatially organized attending to some form of clan or moiety membership.

After $2200 \mathrm{cal}$ BC the internal domestic pattern of Marroquíes Bajos experiences a radical change. Multiple domestic complexes demarcated by stone walls arise as the main feature of this phase (Fig. 7). Their foundation and use have been respectively dated between 2200-1970 calBC (CSIC 1346: 3706 \pm 34 ) and 2140-1950 calBC (CSIC 1344: $3676 \pm$ 30). Dwellings are now built with stone foundations, reaching up to 8 meters in diameter. Open "central" areas are no longer visible, being replaced by extended family households compounds. Separated by alleys, these households incorporate a variety of circular huts, individualized wells, underground storage facilities, ovens, and trash pits. By the time these households are in use, the fifth enclosure has been already backfilled, although its adobe wall is still in use (6). Distributed throughout the site, and probably related to household groupings, are occasional rectangular buildings. These present frontal access corridors, and some include big storage jars and a concentration of loomweights. They represent the first clear case of differential architecture, which may suggests that the control of surplus and specific crafts may have been exercised by certain groups of individuals.

A similar shift from nuclear to extended family households has been recently described by Flannery (2002) as the third stage of village emergence. The author suggests that the economic cause of this development may well be induced by the potential benefits of a larger familiar labor force in covering the needs of cereal agriculture, herding and craft production. As noted by Zafra et al. (1999), the generalization of extended households involves the

(6) Zafra et al. (2003: 85) suggest that all the ditch enclosures had been abandoned by c. 2200 calBC, based on radiocarbon dates obtained from the backfill of the sixth (Ua 20267: $3885 \pm 40$ $\mathrm{BP}=2470-2200 \mathrm{calBC}$ and $\mathrm{Ua} 21455: 3775 \pm 45 \mathrm{BP}=2340-2030$ calBC) and fifth (CSIC 1345: $3705 \pm 28 \mathrm{BP}=2200-1980 \mathrm{calBC})$ ditches. 
institutionalization of forms of property rights nonexistent in the precedent phases. I would further suggest that it also implies an important change in the political economy of the settlement, with a multiplication of both inter-domestic and vertical factionalism.

No more than a century after the emergence of extended households, this system "collapses" (Zafra et al. 1999: 99). The site is then restructured into small and dispersed Bronze Age occupations (Serrano 1999: 253).

\section{PATTERNS}

The spatial analysis developed by Nocete (1989) presents a clear pattern of concentration and dispersal of population throughout the fourth and third millennium BC. This pattern has two key transformations. The first corresponds with the complete disappearance of previous settlements in the Guadalbullón basin during the first half of the third millennium BC (Nocete's phase II and III). The second, the subsequent expansion of settlements throughout the campiña sometime after 2200 BC (phase IV and V). In his latest book (Nocete 2001), the author knows of the existence and dimensions of Marroquíes Bajos, but still does not take it in account. On the contrary, one would suggest that both the existence and internal developments of the site gives us new insights on the evolution of regional patterns.

It is not difficult to see the first shift, the abandonment of the Guadalbullón valley, as a result of an increased flow of population into Marroquíes Bajos. Initially a close cluster of small villages, the site was hypothetically structured as a two ditch enclosure by the early third millennium BC (Zafra et al. 1999: 89). The aggregation initiated at Marroquíes Bajos was contested through an increase in regional intergroup strife, as may suggest the sequential investment of labor in the fortification of both Los Alcores and Albalate, located $20 \mathrm{~km}$ away from the Guadalbullón. A center-periphery narrative could see these sites as the "spearhead" of Marroquíes in the control of the Salado basin. Nevertheless, it seems reasonable to consider that the main problem during the process of aggregation would be the actual control of internal labor force.

By the mid third millennium BC, the population aggregated at Marroquíes Bajos had built a 113 ha site, with five concentrical ditched enclosures, one of them with an attached adobe wall. The scale, complexity of collective labor investments, simplicity of its early domestic forms, and absence of evidence for individual accomplishments, fall close to what has been defined as corporate or group oriented societies (Blanton et al. 1996; Earle 2001; Renfrew 1974; 2001). All the other sites in the region have less than 20 hectares in size and are dispersed throughout the west of the campiña and the Salado basin.

The second shift is an increase of up to 62 sites throughout the region (fig. 4). More than the expression of incoming population attracted towards the "regional center", this pattern seems to be the result of a fission process originated at Marroquíes Bajos, when increasing options for surplus extraction by emerging corporate chiefs may have been contested through a loss of labor force. Extended households and backfilling of ditched enclosures show a radical change in the internal structure of the site. An important amount of population flees Marroquíes Bajos, colonizing the less productive areas of the campiña. As would be expected if lineage groups escape from their former increasingly powerful chiefs, the new settlements do not reproduce the extended household pattern. In fact, as the site of Cazalilla shows, a more "communal" form was recreated.

The final stage is the collapse of Marroquíes Bajos and the gradual abandonment of the other potential regional center, Los Alcores. The emerging Bronze Age will not be an increasingly complex evolution of Copper Age patterns, but the result of their fragmentation.

\section{SUMMARY}

The complex "perimetrics" (Stone 1994) of the settlement walls and hydraulic system (whether the latter is intentional or a by-product) no doubt required initial planning and leadership. The ways in which population was attracted to carry out the task are difficult to assess. As has been noted, an increase of regional warfare may have triggered the aggregation. Other than that, one would suggest that archaeological evidence of large scale feasting and/or collective-inclusive ritual facilities should be expected. Nevertheless, evident non-funerary ritual facilities are absent in most known Copper Age sites in Iberia.

During the early phases of the site, when the 
ditched and walled system was erected, there is no variability in domestic facilities that can be attributed to wealth differentiation (rather than to variable domestic functions). However, when primary labor investments were over, the evolution of the site was marked by an increase in building differentiation, institutionalization of the extended family household as independent units of production and, not surprisingly, a sequential loss of population. Consequently, corporate chiefs would have suffered an increased instability in their finance.

A critical question arises: where are the chiefs? Because chiefs are a "incipient aristocracy with advantages in wealth and lifestyle" (Earle 1987: 290), one would expect that these advantages would somehow show in the archaeological record. The most promising and accessible line of evidence comes from architectural differentiation. The dispersed appearance of rectangular buildings would favor their interpretation as "chiefly" households or open-air storage facilities potentially manipulated by them in their own advantage. The importance in the shift from underground to this kind of storage would have increased the options for exclusive surplus appropriation or manipulation. Nevertheless, the nature of the activities performed in these special architectural features is still to be assessed.

It should be noted that references to "prestige items" have been absent throughout the discussion. The relative irrelevance of a "wealth finance" (D'Altroy and Earle 1985) during the Copper Age has been already noted by several authors (Gilman 2001; Montero 1994; Rovira 2002; but see Gilman 1987). If anything, Prehistoric Iberia was a staple finance based society. Although increasing surplus may have been accessible to promote differential appropriation, staples were not transformed into durable objects, a means by which most elites amass wealth and express exclusion. Of course, other forms of social storage (Halstead and O'Shea 1982; Ingold 1983) may have operated. The transformation of surplus generated from agricultural production into domestic flocks would have implied a stable and movable wealth to manipulate. Unfortunately, no evidence of this kind of accumulation is currently available, mainly because of the quantitative and qualitative scarcity of animal bone samples in all published sites (Nocete 1994a) except Polideportivo de Martos (Lizcano et al. 1997), and the lack of information from Marroquíes Bajos. In any case, the possible existence of economic inequalities need not imply political ones (Chapman 2003: 79).
One key conclusion can be derived from this case study. When collective surplus labor is no longer invested in public construction, the interests of domestic units confronted those of leaders, both being increasingly materialized. If leaders are unable to institutionalize their power during these early stages, creating efficient tributary mechanisms, increasing resistance and fission undermine their emerging leadership. The rising importance of domestic units, in the absence of renewed communal labor investments, would have multiplied the frontlines of horizontal factionalism, thus eroding the base of chieftain's power. That is, the initial mobilization of labor becomes the key moment to stabilize institutionalized political and economic power. Unstable chiefly power is to be expected unless chieftains break through the social and ideological restrictions that support kinship-based modes of surplus extraction at this early stage. Even under certain levels of intensification, the lack of means to maintain their initial pool of labor force would undermine their main resource of finance. Conflicting interests were displayed in the interplay between the personal ambitions of emerging chieftains and the increasing independence of the domestic sphere. Factionalism would have increased in both vertical and horizontal social relations. These contradictory dynamics create an increasing social tension, documented in the archaeological record as a form of political "collapse": the restructuring of lineages and renegotiations of power relations through a new cycle of segmentation.

\section{BEYOND MARROQUÍES: FACTIONAL PROCESSES IN COPPER AGE IBERIA}

The conclusions derived from examination of Marroquíes Bajos and the Guadalquivir campiña would be of limited importance if they could not be extrapolated to other cases. Recent (and as yet preliminary) investigations of large Copper Age sites in other parts of southern Iberia suggest that similar processes may be at work.

This appears to be true at Los Millares, perhaps the most important case because of the site's international fame. The standard model of the site's development indicates that by the height of the Copper Age (3000-2600 calBC) there was a large settlement with four fortification walls and ten small forts that functioned to protect "the southern 
flank of the settlement for over two kilometers" (Arribas and Molina 1984: 1037). Politically, Los Millares "would be a centralized state that directed the exchange networks of prestige goods" (Molina et al. 2004: 155). However, the contemporaneity of the largest phase of the settlement and the forts was contradicted by the late date for fort 1 (Montero 1996: 182). The new series of absolute dates (Molina et al. 2004) does not resolve this problem (Fig. 8): the use and abandonment of forts 1,4 and 5 fall in the second half of the III millennium calBC, and the critical evidence for the date of their foundation is lacking. By 2500 cal BC fortification lines I and II had been abandoned (although the latter has evidence for a later constructional phase [ibid.: 152]). For fortification wall III an abandonment date of 2865-2400 cal BC is suggested, while fortification wall IV is the only one that we can be sure continued in use during the second half of the third millennium.

As for now, the excavators of Los Millares continue to defend their original interpretation that the forts were established between 3000 and $2600 \mathrm{cal} \mathrm{BC}$. This is a reasonable hypothesis, but one that lacks absolute dates to back it up: the six dates for the use of fort 1 are all associated with its later moments of occupation. If this chronology is correct, the end of Los Millares might be interpreted as a process of disaggregation that began in the mid-third millennium cal BC, when multiple lines of evidence suggest that most of the settlement was abandoned and the forts occupied (Carrilero 1992: 974-975; Rovira 2002: 11). This model would reinforce the interpretation of the crisis of Los Millares as the result of a political dynamic involving competition between lineages (Gilman

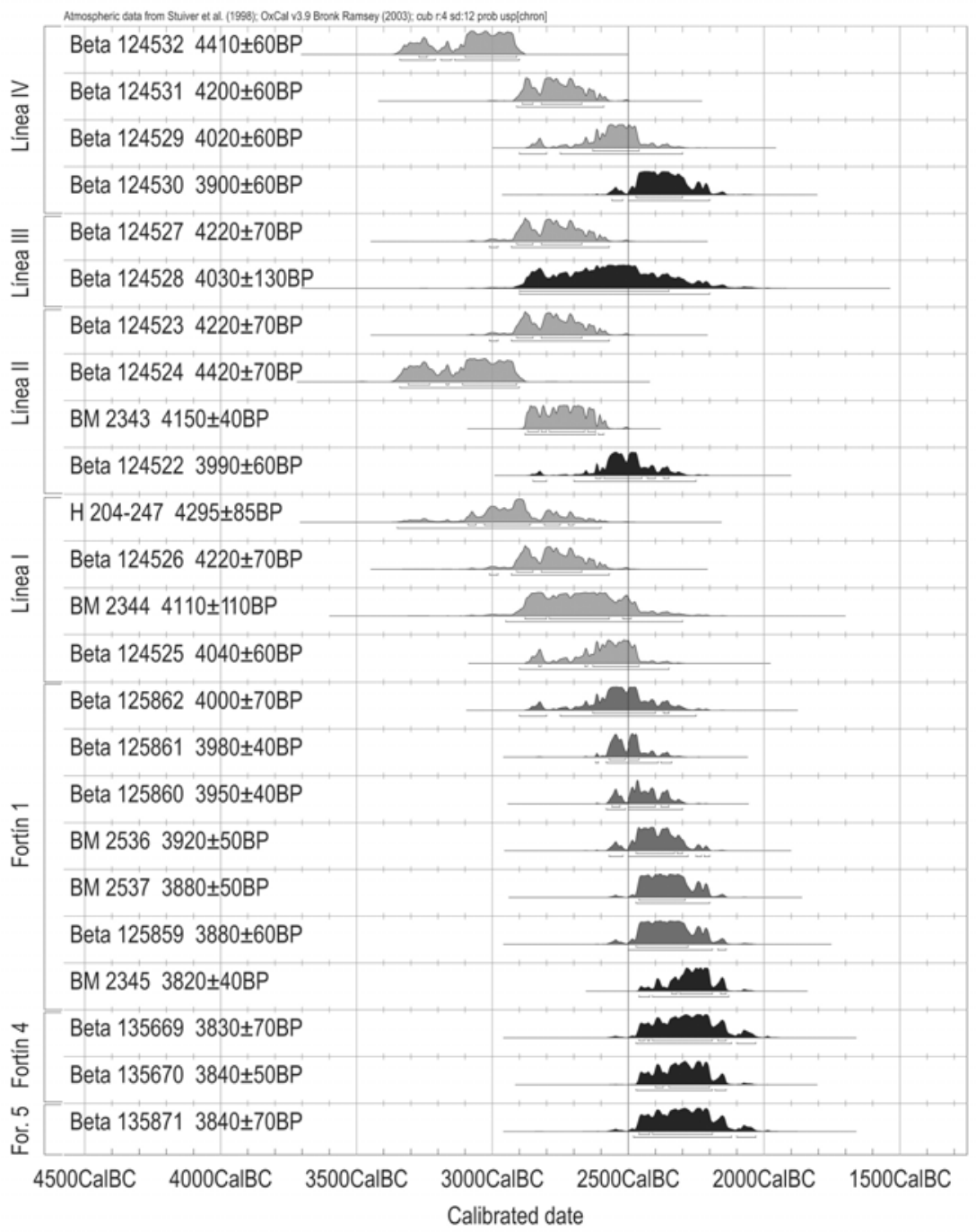

Fig. 8. Calibrated radiocarbon dates (Oxcal v3.9) from Los Millares (following Molina et al. 2004). In light grey, use phases of the main settlement; in dark grey, use phases of Fortín 1; in black, abandonments.

2001), a dynamic of fusion and fission observed on a much larger scale at Marroquíes Bajos.

Other parts of southern Iberia exhibit evidence of large-scale processes of aggregation, the most notable (by reason of their size) being Valencina de la Concepción (Vargas 2003), La Pijotilla (Hurtado 2000) and Perdigões (Lago et al. 1998), all associated with megalithic funerary monuments. The large size of these sites is usually explained in terms of their political and economic centrality and the corresponding dependency of smaller sites in their vicinity. The assumption is that variability in size between settlements necessarily reflects relations of political dependence. This line of argu- 
ment does not take into account several considerations. In the first place, it does not specify what economic, social and/or political mechanisms triggered the processes of aggregation. In the second place, it does not state where the settlers came from: unless the immigration of external groups can be demonstrated, any process of aggregation necessarily involves the reduction of population in the vicinity of the developing nucleus. Finally, the contemporaneity and permanence of all these Copper Age settlements, large and small, remains to be demonstrated, a problem whose resolution would necessitate refining the available chronology, a difficult matter given the limitations of the archaeological record and the statistical error of absolute dates. All the same, it seems reasonable to suppose that there existed considerable differences in the dates of initial occupation and abandonment of both large (Hurtado 2000) and small (Valera 2003: 145) sites.

The model of factionalism and competition between lineages suggested in this work envisions processes of both aggregation and dispersal and is consistent with the limited available archaeological information. One might ask why the processes of large-scale aggregation we see in parts of southern Iberia did not take place in other parts of the peninsula such as the Meseta, Galicia, or Cantabria or even parts of Andalusia like the paradigmatic Millares itself. Although similar variability is documented in other areas in the Copper Age and in other periods (e.g., Usman 2004; Varndell and Topping 2002), in the Iberian Peninsula grand center-periphery narratives require a better empirical base (Chapman 2003: 173). It is evident that the minimal condition required for aggregation to take place is the prior existence of a sufficiently dense regional population and the environment and technology to sustain it. As Brumfiel (1994: 7) has argued, "under conditions of low agricultural intensification, faction leaders will do best in areas [...] where a large following can gather to enjoy the benefits of factional membership without incurring the costs of intensified subsistence effort". Of course, testing this hypothesis would require further research, a matter that goes beyond the limits of the present contribution.

To address archaeologically the dynamics of fusion and fission with greater accuracy we will need more and better regional analyses. In any case, the challenge will be to undertake them in political terms.

\section{ACKNOWLEDGMENTS}

I have greatly benefited from the comments of Jim Brown, Leonardo García Sanjuan, Maribel Martínez Navarrete, Juan Vicent, and Robert Chapman, who reviewed and edited an earlier draft. I am specially grateful to Antonio Gilman for both his critical comments and exhaustive editing of the final version.

\section{REFERENCES}

ARRIBAS, A. and MOLINA, F. 1984: "The latest excavations of the Copper Age settlement of Los Millares, Almeria, Spain”. In W.H. Waldren, R. Chapman, S. Lewthwaite and R.C. Kennard (eds.): The Deya Conference of Prehistory. British Archaeological Reports International Series 229 (iii): 1029-1050.

BECK, R.A. JR. 2003: "Consolidation and Hierarchy: Chiefdom variability in the Mississippian Southeast". American Antiquity 68(4): 641-661.

BLANTON R.; FEINMAN, G.; KOWALEWSKI S. and PEREGRINE P. 1996: "A Dual-Processual Theory for the Evolution of Mesoamerican Civilization". Current Anthropology 37: 1-14

BROWN, J.A. 1997: “The Archaeology of Ancient Religion in the Eastern Woodlands". Annual Review of Anthropology 26: 465-485.

BRUMFIEL, E.M. 1992: "Distinguished Lecture in Archeology: Breaking and Entering thee Ecosystem Gender, Class, and Faction Steal the Show". American Anthropologist 94 (3): 551-567.

- 1994: "Introduction". In E. Brumfiel and J.W. Fox (eds.): Factional competition and political development in the New World. New Directions in Archaeology. Cambridge University Press. Cambridge.

BRUMFIEL, E.M. and FOX, J.W. (eds.) 1994: Factional competition and political development in the New World. New Directions in Archaeology. Cambridge University Press. Cambridge.

BUJRA, J.M. 1973: "The Dynamics of Political Action: A New Look at Factionalism". American Anthropologist 75 (1): 132-152.

BURGOS, A.; LIZCANO, R. and PÉREZ, C. 2001a: “Actuación arqueológica realizada en el espacio destinado a la instalación del ovoide del vial 4 de la UA-23. Marroquíes Bajos. Jaén". Anuario Arqueológico de Andalucía 1998, III Actividades de Urgencia I: 422-428.

- 2001b: "Actuación arqueológica realizada en el bloque A de la UA-25 de Marroquíes Bajos de Jaén". Anuario Arqueológico de Andalucía 1998, III Actividades de Urgencia I: 414-421.

- 2001c: "Actuación arqueológica realizada en la piscina comunitaria de los bloques A1, A2, A3, A6, A7 y A8 
del sector UA-23 de Marroquíes Bajos de Jaén”. Аnиario Arqueológico de Andalucía 1998, III Actividades de Urgencia I: 402-413.

CÁMARA, J.A. 2001: El ritual funerario en la Prehistoria Reciente en el Sur de la Península Ibérica. British Archaeological Reports International Series 913. Oxford.

CHAPMAN, R.W. 2003: Archaeologies of complexity. Routledge. London.

CLASTRES, P. 1980: Recherches d'anthropologie politique. Seuil. Paris.

D'ALTROY, T. and EARLE, T.K. 1985: "Staple Finance, Wealth Finance, and Storage in the Inca Political Economy". Current Anthropology 26: 187-206

DEMARRAIS, E.L.; CASTILLO, J. and EARLE, T.K. 1996: "Ideology, Materialization, and Power Strategies". Current Anthropology 37: 15-31.

DIETLER, M. and HAYDEN, B. (eds.) 2001: Feasts: archaeological and ethnographic perspectives on food, politics, and power. Smithsonian Institution Press. Washington DC.

EARLE, T.K. 1987: "Chiefdoms in Archaeological and Ethnohistorical Perspective". Annual Review of Anthropology 16: 279-308.

- 2001: "Economic support of Chaco Canyon Society". American Antiquity 66 (1): 26-35.

FLANNERY, K.V. 2002: "The origins of the village revisited: from nuclear to extended households". American Antiquity 67 (3): 417-433

GILMAN, A. 1987: "Unequal development in Copper Age Iberia". In E.M. Brumfiel and T.K. Earle (eds.): Specialization, exchange, and complex societies. New Directions in Archaeology. Cambridge University Press. Cambridge: 22-29.

- 1991: "Trajectories towards social complexity in the later prehistory of the Mediterranean". In T.K. Earle (ed.): Chiefdoms: Power, Economy, and Ideology. Cambridge Univeristy Press. Cambridge: 146-168.

- 1995: "Prehistoric European Chiefdoms. Rethinking 'Germanic' Societies". In T.D. Price and G.M. Feinman (eds.): Foundations of Social Inequality. Plenum Press. New York: 235-251.

- 2001: "Assessing Political Development in Copper and Bronze Age Southeast Spain”. In J. Haas (ed.): From Leaders to rulers. Kluwer Academic/Plenum Publishers. New York: 59-81.

GODELIER, M. 1978: "Infrastructures, Societies, and History". Current Anthropology 19(4): 763-771.

HALSTEAD, P. and O'SHEA, J. 1982: “A Friend in Need is a Friend Indeed: Social Storage and the Origins of Social Ranking". In C. Renfrew and S. Shennan (eds.): Ranking, Resource and Exchange. Cambridge University Press. Cambridge: 92-99.

HARRISON, R.J. and GILMAN, A. 1977: "Trade in the Second and Third Millennia B.C. between the Maghreb and Iberia”. In V. Markotic (ed.): Ancient Europe and the Mediterranean. Studies presented in honour of Hugh Hencken. Aris and Phillips, Warminster: 91104.

HARRISON, R.J. and OROZCO, T. 2001: "Beyond characterisation. Polished stone exchange in the Western Mediterranean 5500-2000 BC". Oxford Journal of Archaeology 20 (2): 107-127.

HORNOS, F.; ZAFRA, N. and CASTRO, M. 1998: "La gestión de una zona arqueológica urbana: la experiencia de investigación aplicada en Marroquíes Bajos (Jaén)". Boletín del Instituto Andaluz de Patrimonio Histórico 22: 82-91.

HURTADO, V. 2000: "Surface analysis ofthe copper age settlement of La Pijotilla (Spain)". In R. Francovich and H. Patterson (eds.): Extracting meaning from ploughsoil assemblages. The Archaeology of Mediterranean Landscapes 5. Oxbow. Oxford: 121-131.

INGOLD, T. 1983: "The Significance of Storage in Hunting Societies". Man 18 (3): 553-571.

KNIGHT, V.J. 1986: "The institutional organization of Mississippian religion”. American Antiquity 51: 657687.

KOPYTOFF, I. 1999: "Permutations in patrimonialism and populism: The Aghem chiefdom of western Cameroon". In S.K. McIntosh (ed.): Beyond Chiefdoms. Pathways to Complexity in Africa. New Directions in Archaeology. Cambridge University Press. Cambridge: 88-96.

KRISTIANSEN, K. 1984: "Ideology and material culture: an archaeological perspective". In M. Spriggs (ed.): Marxists perspectives in archaeology. Cambridge University Press. Cambridge: 72-100.

LAGO, M.; DUARTE, C.; VALERA, A.; ALBERGARIA, J.; ALAMEIDA, F. and CARVALHO, A.F. 1998: "Povoado dos Perdigões (Reguengos de Monsaraz): dados preliminares dos trabalhos realizados em 1997'. Revista Portuguesa de Arqueologia 1 (1): 45-152.

LIZCANO, R.; CÁMARA, J.A.; CONTRERAS, F.; PÉREZ, C. and BURGOS, A. 2004: "Continuidad y cambio en comunidades calcolíticas del Alto Guadalquivir". III Simposio de Prehistoria Cueva de Nerja. Vols. II y III. Nerja: 159-175.

LIZCANO, R.; CONTRERAS, F.; PÉREZ,C.; CÁMARA, J.A.; and BURGOS, A. 1997: "El Polideportivo de Martos. Estrategias económicas y símbolos de cohesión en un asentamiento del Neolítico Final del Alto Guadalquivir". Cuadernos de Prehistoria de la Universidad de Granada 16-17 (1991-1992): 5-101.

MANN, M. 1986: The Sources of Social Power. Volume 1. A History of Power from the Beginnings to AD 1760. Cambridge University Press. Cambridge.

MCINTOSH, R.J. 1991: "Early Urban Clusters in China and Africa: The Arbitration of Social Ambiguity". Journal of Field Archaeology 18 (2): 199-212.

MOLINA, F.; CÁMARA, J.A.; CAPEL, J.; NÁJERA, T. and SÁEZ, L. 2004: "Los Millares y la periodización de la Prehistoria Reciente del Sureste". III Simposio de 
Prehistoria Cueva de Nerja. Vols. II y III. Nerja: 142158.

MONTERO, I. 1994: El origen de la metalurgia en el sureste peninsular. Instituto de Estudios Almerienses. Almería.

- 1996: “NNovedades sobre el Calcolítico? Te mantendremos informado". Trabajos de Prehistoria 53 (2): 178182.

NOCETE, F. 1989: El Espacio de la Coerción. La transición al estado en las campiñas del Alto Guadalquivir (España), 3000-1500 a.C. British Archaeological Reports, International Series 492. Oxford.

- 1994a: La formación del estado en las campiñas del Alto Guadalquivir (3000-1500 a.n.e.). Análisis de un proceso de transición. Monográfica Arte y Arqueología. Universidad de Granada. Granada.

- 1994b: "Space as Coercion: the transition to the State in the social formations of La Campiña, Upper Guadalquivir Valley, Spain, ca. 1900-1600 BC". Journal of Anthropological Archaeology 13: 171-200.

- 2001: Tercer Milenio antes de nuestra era. Relaciones y contradicciones centro/periferia en el Valle del Guadalquivir. Bellaterra. Barcelona.

PÉREZ BAREAS, C. and CÁMARA SERRANO, J.A. 1999: "Intervención arqueológica en Marroquíes Bajos (Jaén). Sector Urbanístico RP-4, Parcela G-3". Anuario Arqueológico de Andalucía 1995, Vol. III Actividades de Urgencia. Junta de Andalucía: 256270.

PÉREZ BAREAS, C. and SÁNCHEZ SUSI, R. 1999: "Intervención Arqueológica en Marroquíes Bajos, (Jaén). Parcela E 2-4 (Sector UA23)"'. Anuario Arqueológico de Andalucía 1995, Vol. III Actividades de Urgencia. Junta de Andalucía: 271-287.

RENFREW, C. 1974: "Beyond a Subsistence Economy: The Evolution of Social Organization in Prehistoric Europe". In C. Moore (ed.): Reconstructing Complex Societies. Bulletin of the American School of Oriental Resarch 20: 69-95.

- 2001: "Commodification and Institution in Group-Oriented and Individualizing Societies". In W.G. Rucinman (ed.): The Origins of Human Social Institutions. Proceedings of the British Academy 110. Oxford University Press. Oxford \& New York: 93-117.

ROVIRA, S. 2002: "Metallurgy and Society in Prehistoric Spain". In B.S. Ottaway and E.C. Wager (eds.): Metals and Society. British Archaeological Reports International Series 1061. Oxford: 5-20.

RUÍZ, A.; NOCETE, F. and SÁNCHEZ, M. 1986: "La Edad del Cobre y la Argarización en Tierras Giennenses". Homenaje a Luis Siret (1934-1984). Consejería de Cultura de la Junta de Andalucía. Dirección General de Bellas Artes. Sevilla: 271-286.

SAHLINS, M.D. 1961: "The Segmentary Lineage: An Organization of Predatory Expansion". American Anthropologist 63(2): 322-345.

- 1972: Stone age economics. Aldine. Chicago.

SERRANO, J.L. 1999: "Intervención arqueológica de urgencia en Marroquíes Bajos, Residencial Programado 4, Parcela E de Jaén". Anuario Arqueológico de Andalucía 1995 III Actividades de Urgencia. Junta de Andalucía: 249-255.

SHANIN, T. (ed). 1983: Late Marx and the Russian road: Marx and the peripheries of capitalism. Monthly Review Press. New York.

STONE, G.D. 1994: “Agricultural Intensification and Perimetrics: Ethnoarchaeological Evidence from Nigeria”. Current Anthropology 35 (3): 317-324.

USMAN, A.A. 2004: "On the frontier of empire: understanding the enclosed walls in Northern Yoruba, Nigeria". Journal of Anthropological Archaeology 23: 119-132.

VALERA, A.C. 2003: "Mobilidade estratégica e prolongamento simbólico: Problemáticas do abandono no povoamento calcolítico do ocidente peninsular". Era Arqueologia 5: 126-148.

VARGAS, J.M. 2003: "Elementos para la definición territorial del yacimiento prehistórico de Valencina de la Concepción (Sevilla)". Spal 12: 127-146.

VARNDELL, G. and TOPPING, P. (eds.) 2002: Enclosures in Neolithic Europe. Essays on causewayed and Non-Causewayed Sites. Oxbow Books. Oxford.

WOLF, E.R. 1981: Europe and the people without history. University of California Press. Berkeley.

ZAFRA, N.; CASTRO M. and HORNOS, F. 2003: "Sucesión y simultaneidad en un gran asentamiento: la cronología de la macro-aldea de Marroquíes Bajos, Jaén. c. 2500-2000 cal ANE". Trabajos de Prehistoria 60(2): 79-90.

ZAFRA, N.; HORNOS, F. and CASTRO, M. 1999: "Una macro-aldea en el origen del modo de vida campesino: Marroquíes Bajos (Jaén) c. 2500-2000 cal ANE”. Trabajos de Prehistoria 56 (1): 77-102. 